\title{
水利工程造价在设计阶段的控制与管理分析
}

\section{王帅 张巍}

河南省水利勘测设计研究有限公司

DOI:10.32629/hwr.v3i12.2548

[ 摘 要] 造价管控是水利工程设计阶段的一项重要内容,选择技术与经济相融合的方式,贯彻以计划预防为核心, 以纠偏为辅的原则, 能够实现 工程设计阶段造价的有效管控,从而创造更多的经济效益。本文以水利工程为视角,分析了设计阶段工程造价的控制与管理。

[关键词] 水利工程; 造价管控; 设计阶段

从本质上分析, 水利工程的造价管控是贯穿工程全过程的。根据相关 调查与研究, 设计阶段对工程造价的影响占比是 $40 \%$ 左右, 所以加强水利工 程设计阶段造价管控尤为重要。

\section{1 设计阶段造价管控的有效条件}

1.1 大环境对水利工程设计阶段造价管控的有利条件

首先, 政府机构对工程造价管理出台了有关的政策与法规, 尤其是设 计概算方面实现了具体、详细的规定, 由此设计阶段的造价管控必须严格 遵守、把握与应用 ${ }^{[1]}$ 。其次, 造价管控工作极具专业性, 特别是设计阶段造 价管控, 必须由资质雄厚的单位与专业人员负责, 在实践工作时为其赋予 一定权力, 并且应制定合理的责任机制, 以切实提升造价管控成果。

1.2 小环境对水利工程设计阶段造价管控的有利条件

首先, 针对设计阶段中的造价管控, 必须对工程之间的共性与差异有着 深刻认识, 不可以偏概全, 虽然项目参建方在造价管控目标上是一致的, 但 是所需要承担的责任是有所区别的, 所以要准确把握参建方的真正意图, 促 进彼此之间的交流, 从而将设计阶段的造价管控工作形成合力。其次, 相较 于土木工程而言水利工程具有一定的特殊性, 所以造价管控需要安排具有 丰富经验的专业人员负责, 认真、细心地完成造价管控工作, 同时制定科学、 完善的造价管理机制, 提高造价管控成效。

\section{2 设立设计阶段造价管控目标}

在进行水利工程建设时采用的方法与管理手段都是为了能够达成预 期效果, 所以当科学设立造价控制目标之后, 才能够建立有效、可行的造价 管控方法。首先, 投资估算是水利工程设计阶段造价管控方案编制的重要 依据, 结合设计工作实际要求与具体流程, 将造价管控目标进行细化, 如初 步设计目标、技术设计目标以及概算控制目标等 ${ }^{[2]}$ 。其次, 设立造价管控 目标。在水利工程项目设计阶段必须综合分析造价各项影响要素, 并且在 施工图设计过程中实现高精准度的预算。

\section{3 设计阶段造价管控方法的应用}

当确定水利工程项目设计阶段的造价管控目标之后, 唯有制定科学、 有效的工作方法才能够达成预期目标, 从而创造更多的经济效益。水利工 程设计阶段造价控制方法的应用, 具体表现在下述几个方面: (1)针对水利 工程设计阶段的造价管控应用科学管理方法。建立与落实造价管控工作责 任机制, 构建偏差溯源体系, 水利工程项目设计人员必须严格按照标准要 求进行设计, 根据评价体系完成设计文件的审核与评定, 制定可行的奖惩 机制。(2)针对水利工程设计阶段的造价管控应用科学技术方法。在水利工 程项目设计时应保证设计深度与设计质量, 选择先进技术方法, 且设计人 员应具备创新能力与探索精神, 能够准确把握专业技术动态, 引入具有经
济效益性的新方法、新技术, 借助于信息技术实现有价值信息的采集、提 炼, 通过专业软件实现数据分析与处理, 从而保证设计概算全面、高效 ${ }^{[3]}$ 。 (3)针对水利工程设计阶段的造价管控应用科学工作方法。从本质上分析, 造价管控目标需要以建设单位以主, 由此在水利工程项目的设计阶段需要 设计人员积极地与业主进行交流, 了解其造价管控意图, 确定项目总投资 目标等, 以免发生重大错误, 影响经济效益。(4)针对水利工程设计阶段的造 价管控应用科学经济方法。应该综合分析国家当下与未来的经济政策与宏 观调控方向, 有效利用国家政策支持领域的物资, 科学规划水利工程项目 的效益, 制定完善的工作报酬制度, 对于设计阶段造价管控工作表现突出 的单位或者是个人, 应给予奖励, 以点带面, 促进设计阶段造价管控的全 面、有效落实。

\section{4 设计阶段造价管控方法应用的总结与思考}

首先, 对水利工程项目设计阶段的造价管控目标实现状况展开总结, 造 价管控目标实际情况未必完全与预期目标一致, 这也是客观事实存在的, 有 些时候造价管控目标还会比预期目标更好, 有些时候远不如预期目标 ${ }^{[4]}$ 。所 以这就需要对各个阶段的造价管控目标展开汇总评价, 分析主要原因, 然 后总结出最佳的造价管控方式, 并进行优化与完善, 从而为后续工作开展 提供依据。其次, 水利工程的造价管控人员必须认识到设计阶段造价管理 的重要性, 建立有效的造价策略与控制方式并落到实处, 对水利工程项目 建设具有的意义。

\section{5 结束语}

设计阶段的造价管控在水利工程项目的造价管理工作中占据着关键 地位, 也直接关系到工程项目的成败。而水利工程设计阶段造价管控是动 态的, 所以造价管控人员需要综合洞悉工程设计方案, 及时发现与解决造 价管控问题, 并制定科学、可行的造价管控措施, 从而才能够使造价管控实 际情况与预期目标更接近, 甚至是高于预期目标, 创造更多的经济效益。

[参考文献]

[1]罗鸿.水利工程设计阶段造价控制措施探讨 [J]. 黑龙江水 利,2017,3(07):69-71.

[2]张宇珍.水利工程造价在各个阶段的控制管理措施[J].黑龙江水利 科技,2016,44(07):193-194.

[3]王婧.水利水电工程设计阶段工程造价控制刍议[J].广东水利电力 职业技术学院学报,2018,16(04):19-21.

[4]李峰森.浅谈水利工程设计阶段的造价控制与管理 [J]. 智能城 市,2018,4(18):131-132. 